\title{
Time-Driven Activities Based Cost: Evidence of Industrial Firms of Iraq
}

\author{
Khulood Assim Wanas \\ Accounting Department, Baghdad Collage of Economics Sciences University \\ Iraq \\ Email:khuloodal@yahoo.com
}

Received: January 30, 2017 Accepted: February 25, 2017 Published: March 07, 2017

doi:10.5296/ijafr.v7i1.10667 URL: http://dx.doi.org/10.5296/ijafr.v7i1.10667

\begin{abstract}
The main aim of this paper is to justify the concept of Time-Driven Activity Based Cost (TD$\mathrm{ABC}$ ) system. It tries to analyze the principles and dimensions of this system. Through this paper an illustration of the beneficial effect of the modern accounting system and the way in which it can replace the currently used system has been analyzed. The system has been proposed to be implemented in the Industrial Companies of Iraq. Hence, the top-notch managers of few industrial companies have been taken as a sample of this research. The research was conducted by forming a questionnaire and verifying the result of the questionnaire with respect to the research question. The research also proposes 5 hypotheses that have been tested in order to come up with a proper conclusion of our objective.
\end{abstract}

Keywords: Activity based cost system, Time-driven activity based cost system and Iraqi industrial firms. 


\section{Introduction}

The world can be exemplified by three particular words namely, "communication, technology and competition." These factors have generated the need to change the mechanism used for production in order to increase the same. Due to the increased production, the market faces the need to focus on establishing a proper costs system. The accounting and financial decision of the firms are taken by the top management leaders. 1980 saw the shift in the accounting system from the traditional method to the newly introduced Activity Based Costing system. Even after so many years of its introduction, the system was not universally accepted and it faced several criticisms globally. Along with the advancement of time, there has been an increase in the cost associated with the system and hence many firms have discarded this system. There has been a shift in the costing system from the ABC system to the Time-Driven Activity Based Costing system. This system can adapt itself with the rapidly changing environment and thereby provides the most accurate information as required at the different managerial levels of the firms.

\section{Literature Reviews}

The system of $\mathrm{ABC}$ has been used in various sectors through the global market since early 1980s. This system was used in the different firms to ensure accuracy of the cost figures after incorporation of the indirect costs. Though, the system provided the figures with accuracy but there has been some serious flaws associated with the system. The system needs upgradation on a daily basis and incurs a huge cost of operation. After realizing the flaws of the traditional system, Anderson and Kalpan introduced the modern version time driven version of the Activity Based Costing system. This system is cost-effective and comes with the ease of operation and up-gradation.

Anderson and Kalpan has also provided a justification for introducing this method. According to them, they took seven cases from the market that were in practice to find out the ways in which both the system differs. In doing so they came up with the solution where the management of the company can bebenefitted by using the time equations can help in understanding the required time, cost of unit and activities involved using the available resources.

According to Schuhmacher and Burkert, there are several differences in both the system. Through this paper, the pros and cons of the TD-ABC system has been evaluated in details. It has been shown that the traditional system neglected the overhead cost and its arbitrary allocation. The TD-ABC tries to evaluate the ways in which the actual energy influences the fixed factors of productions thereby influencing the total production of the economy.

According to the paper presented by Hon and Chu, the result of a case study has been presented whereby the author tried to pose a comparison between the systems and analyze the difference of the two on the basis of the production capacity. Also, the analysis tried to identify the wastages involved in both the system and focus on the short-comings of the same. According to the findings, it can be said that the time driven method can be used to highlight the actual waste of the production system and also indicates the untapped energy in 
the system has been highlighted. Since, the TD-ABC system uses unit factor for observing the changes in activity of production hence the company using this system gets more accuracy in estimating their cost.

\subsection{Application of the steps of TD-ABC}

There were shortcomings of the system of $\mathrm{ABC}$ in measuring the true cost of a production process. In order to overcome these short-comings the new TD-ABC has been designed. Through this system calculations can be made faster, simpler and would incur less cost. The steps in which this TD-ABC is going to work to deduce the accurate cost of any production system are given as follows:

- Initially the different groups or stages where costs are incurred needs to be identified. Also the departments where these costs are implemented are identified.

- The cost varies for different groups of resources used in the production process. These costs need to be estimated.

- The system of TD-ABC helps in identification and estimation of the resources to produce certain quantity of output. This estimation also includes the time where no work has been done during the office hours due to some situations like attending meetings, going to workshops, lunch hours and few other things like these. The practical or actual capacity of each group needs to be observed too.

- The next step involves calculating the unit cost of each departments involved in the production process. It is done by dividing the total cost incurred by the use of energy resources with the total size of the operation taken.

- This step is the most crucial one whereby the expected time required for conducting the different events based on the activities involved are estimated by using the available time equation.

- The final step involves measuring the total cost of the process including the per unit cost of time.

The TD-ABC is calculated based on cost engine. Cost engine is the property of this system to differentiate the required time for each activity depending on their nature. The total time taken in completing a production process is calculated based on the time involved in each segment of the production process.

\subsection{Mechanisms for determining the Time-Drivers}

The basic principle involved in this method is the way in which cost system is interpreted in terms of time by transforming the cost system into time based equation. This system tries to find out the time consumed by each different activity. This method involves the crucial step of expressing each activity within a time frame and analyzing them on that basis. It can be done mathematically by using algebraic formulae. This mathematical description has been provided in the next page. 


$$
T_{\alpha}=\beta_{0}+\beta_{1} X_{1}+\beta_{2} X_{2}+\beta_{3} X_{3}+\ldots+\beta_{n} X_{n}
$$

Whereas:

$T_{\mathrm{ax}}$ The time required to complete the event $K$ in activity $j$.

$\beta_{0}$ Fixed amount of time activity $j$ received for the characteristics of the event $k$.

$\beta_{1}$ Time spent or expired for unit of reasoned first time

$X_{1}$ Reasoned the first time for the activity, $X_{2}$ reasoned the second time for the activity, $X_{n}$ reasoned time $n$.

$n$ Number of time causes that determine the time required for completion of activity $j$.

It has been account the cost of activity as follows:

Activity cost $=$ the time required for the activity $x$ cost per unit time

Time required for Activity $=$ Time required for each event $k$ of activity events

Cost of event $\mathrm{K}$ for activity $j=C_{i} \times T_{j}$

Whereas:

$T_{j}$ Time spent to process $(k)$ in the activity $j$.

$C_{i}$ Unit of time cost of resources group (i)

It is assembled all the costs of activities to arrive at the total cost of the goal of cost (client, service, product)

The total cost to the goal of cost $=\sum_{i=1}^{n} \sum_{j=1}^{m} \sum_{i=1}^{i} T_{k j} C_{i}$

Whereas:

$C_{i}$ Unit of time cost of resources group (i)

$T_{\text {j }}$ Time spent to process $(k)$ in the activity $j$.

$n$ The number of resource pools, $m$ the number of activities, $i$ the number of times consuming activity $j$.

\subsection{The advantages of application of the TD-ABC}

The expediency of the theory of time driven activity based costing system is given as follows:

- This system can estimate the data available in any model with accuracy and within a short span of time.

- The validation of the cost incurred by the company can be verified through direct monitoring under this system.

- The model can easily take into consideration and reflect any changes that may occur within an organization's operation.

- As time is the prime factor of this model, therefore, with the advent of time the model can easily reflect the changes in the company's orders and customer behavior keeping all other parameters of the model same.

- TD-ABC disregards the necessity to conduct any interview for recognizing while recruiting the staff members. 


\section{Macrothink}

International Journal of Accounting and Financial Reporting

ISSN 2162-3082

2017, Vol. 7, No. 1

- The system can be used on a regular basis to understand and analyze the economics behind the operational issues of the organization.

- The most beneficial feature of this system is that it can help the company in identifying the total amount of workers that remain idle. This data can help the company in setting up a modified structure of recruitment procedure. Through this feature the company can also decide upon mobilization of its human resources between its sectors and recruiting the optimal number of employees so that output can be maximized whereas all employees perform optimally.

\section{Research Methodology}

\subsection{Research Objectives}

Any research must have certain pre-defined objectives based on which the researcher tries to find out formulate and organize the researches. Similarly, the focus and aim of this research has been given as follows:

- The research tries to lay importance on the flaws of the existing activity based costing system. A strong criticism needs to be proposed in order to advice the organization to change the system into TD-ABC.

- After the flaws of the traditional existing system have been identified the research carries on seeking the concept of the new system. It also tries to focus on finding the dimension and principle of TD-ABC and highlights the need to implement the same.

- This paper then tries to understand the existing conditions of the industrial companies of Iraq which can help in progress of the application of TD-ABC. It also tries to find out if at all there is any base within this industry which can help in creating an environment for transitioning into a new system of accounting.

\subsection{Importance of the Research}

Through this research, it has been tried to find out the following two issues:

- The importance and requirement of applying time driven activity based cost system in the Industrial Companies of Iraq.

- The ability of the industrial companies of Iraq to adopt the system within their industrial domain has been tried to analyze.

\subsection{Problems associated with the Research}

During the time period of 1980s, there was a shift in the accounting system from the then existing traditional method into the presently used Activity Based Costing system. With the advancement of time, the initially attractive $\mathrm{ABC}$ system now faces several problems and requires up-gradation. Along with modernization of industries, there has been an increase in complexity of the process of production. The ABC fails to segregate and highlight the cost associated with this modern day complex process. Hence, a new system which can account for the changes in time and disintegrate the complexities of the production process has been 
proposed. This system is known as TD-ABC. Through this research the importance of this system has been tried to analyze and the research question that this report is going to answer is given as:

"Is the environment of the Iraqi Industrial Companies suitable to implement the modern system of TD-ABC?"

\subsection{Hypotheses taken for this research}

The research starts with the assumption that there is dearth of availability of the basic principles that can help in proper implementation of the system of TD-ABC in the IICs. With this assumption the hypotheses taken into consideration are:

1. The top-management supports in adopting and implementing the new tools of accounting system named as TD-ABC.

2.The second hypothesis states that there is existence of professional and scientific scope within the IIC that lays the base for implementation of the modern system.

3. Existence of the high level system of accounting that can support or provide back-up to the newly system proposed to be implemented.

4. The extent to which the production processes of IIC are complex and the diversity in their products that require that generates the need to apply TD-ABC.

5. TD-ABC's application and implementation within the industrial domain of Iraq is economically justified.

\subsection{The Study: Sample \& Population}

The top level financial managers, production managers and members of the managing committee from the industrial companies of Iraq has been selected to form the sample of members used in this research paper. The samples have been carefully selected keeping in mind that the people in the sample should possess the knowledge and know-about of the existing system of activity based costing system. They are the ones who should also have the knowledge about the flaws of the existing system and theories related to the new system named TD-ABC that is going to be implemented in the market. This study has been conducted into two phases:

Phase 1: Here a survey has been made on the companies who presently uses ABC system and possess knowledge about the TD-ABC.

Phase 2: A questionnaire was prepared and surveys conducted accordingly. The questionnaire designed was based on previous studies and literatures regarding this field and the survey made in Phase 1.

\subsection{Designing the Questionnaire}

The questionnaire has been designed with the motive to come up with the answers of the proposed research question. While constructing the questionnaire, the technique suggested in 


\section{Macrothink \\ International Journal of Accounting and Financial Reporting \\ ISSN 2162-3082 \\ 2017, Vol. 7, No. 1}

the Likert Five-Point Scale has been used. The questionnaire contained 3 parts:

Part 1: It contains an introduction about the system and definitions of the key terms that clears the concepts of TD-ABC and helps the people to answer part 2 and 3.

Part 2:This part of the questionnaire contains question to get a general view of the respondents on the demographics of the sample and the particular cases of TD-ABC system.

Part 3: This part of the questionnaire is the most crucial one where questions relating to topics of the chosen hypotheses have been asked. The answers to this portion of the questionnaire are crucial in determining the validity of our chosen hypothesis.

\subsection{Stability of this Questionnaire}

Stability of questionnaire is of utmost importance while conducting any research. By the term stability, in this context we mean that even if the questionnaire is distributed to other respondents, it is going to fetch the same answer. Even if all the answers do not turn up to be same, the re-distribution of questionnaire is going to yield answers that are in consistency with the previous ones. To check the reliability of the questionnaire, the Cronbach-Alpha correlation coefficient has been used. If any parameters show 0.88 positive correlations, then it has been taken to be reliable and consistent enough to use for further analysis.

\subsection{Inference drawn from the Questionnaire}

The questionnaires have been distributed amongst the sample in our study. The total responses that have been derived from distribution of this questionnaire have been shown in Table 1 and 2 below:

Table 1

Distribution of the questionnaire on the study saniple

\begin{tabular}{lcc}
\hline Statement & No. & $\%$ \\
\hline Questionnuires distributed & 82 & 100 \\
Questionnaires recovered & 64 & 78 \\
Questionnuires is un recovered & 18 & 22 \\
Analyzable questionnaires & 64 & 78 \\
\hline
\end{tabular}

Table 1: Distribution of Questionnaire

Source: As Created by the Author 


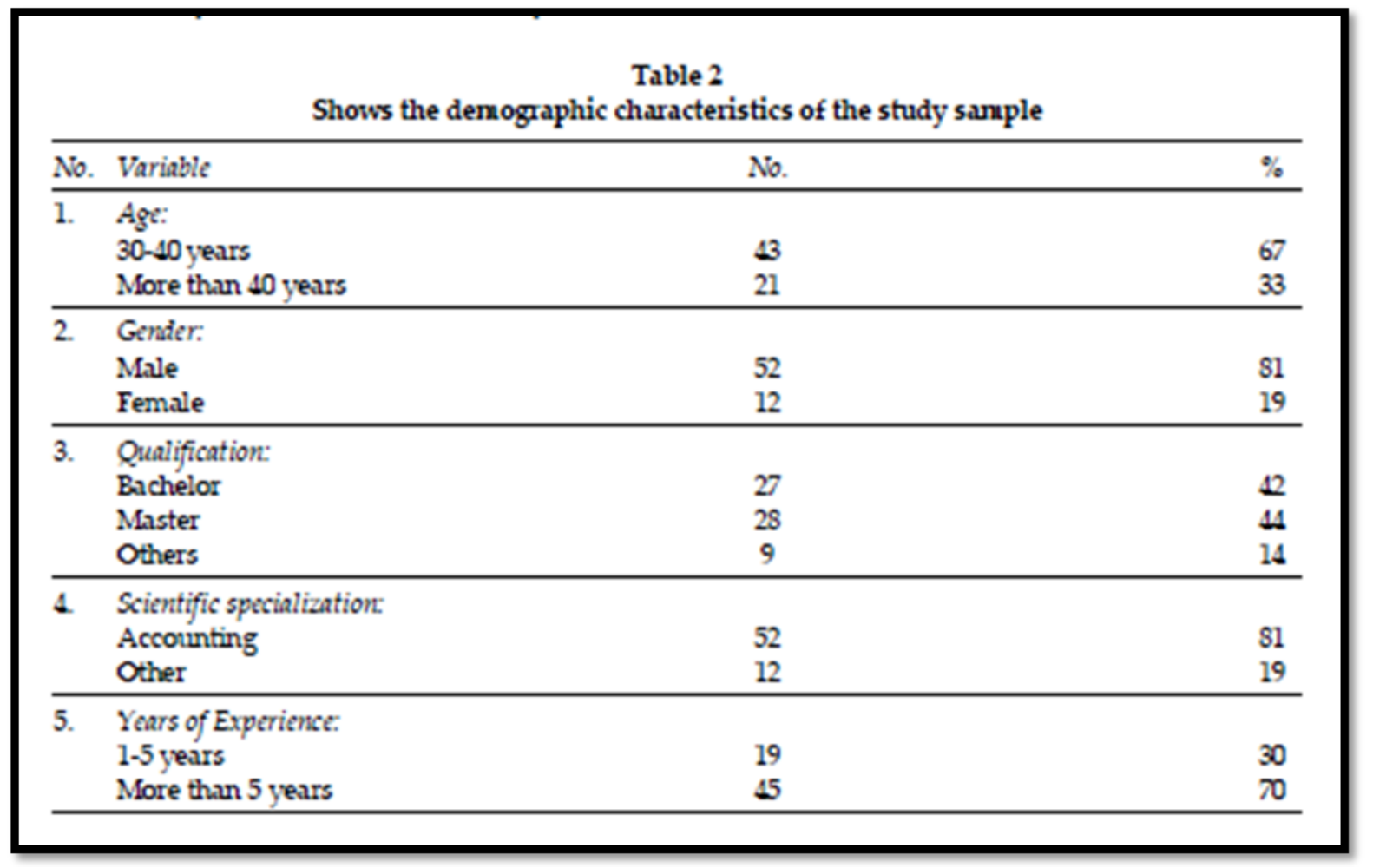

Table 2: Demographic Characteristics of Sample

Source: As Created by the Author

From the above two table the inference that can be drawn are as follows:

1. According to the study it has been found that the qualification of most of the sample is either a degree in bachelors or in masters. This implies that they are knowledgeable enough to understand the write up of the questionnaire and answer properly to those questions. This helps us in attaining the goal by receiving authentic answer.

2. From the questionnaire it can also be said that people with experience provides more consistent answers with full confidence.

\subsection{Descriptive Data}

\subsubsection{Descriptive Statistics of the variables used in Study}

Table 3 highlights facts based on the ways in which management has supported the system of TD-ABC. The ways, in which the company prepares themselves for implementing this process, the perspective of the company regarding their ability to successfully implement the system has been highlighted through this table. The findings from the case study of industrial companies of Iraq highlight the fact that positive weightage has been given to all the criteria and the weightage is above $60 \%$. The relative weightage given to the all the variables in total is around 66\%. From the table below it can be connoted that the higher authority in the managerial department of the company is eager to implement the newly launched strategy. The findings in table 3 are in consistency with the literatures related to this topic. 


\section{Ml Macrothink}

International Journal of Accounting and Financial Reporting

ISSN 2162-3082 2017, Vol. 7, No. 1

\begin{tabular}{|c|c|c|c|}
\hline \multicolumn{4}{|c|}{$\begin{array}{l}\text { Table } 3 \\
\text { The results of descriptive statistics for paragraphs of variable support the top management in Iraqi } \\
\text { industrial companies to apply TD-ABC }\end{array}$} \\
\hline No. Paragraphs & mean & $\%$ & St.d \\
\hline $\begin{array}{l}\text { 1. Top management supports applying the modem systems from both material } \\
\text { and moral aspects. }\end{array}$ & 108 & 82 & 0.56256 \\
\hline $\begin{array}{l}\text { 2. The manigement of company has the ability to in close the activities that } \\
\text { expired from each product. }\end{array}$ & 3.39 & 68 & 0.54167 \\
\hline $\begin{array}{l}\text { 3. The management of company has the ability to prepare and apply the } \\
\text { equations of the time required for each activity of its activities. }\end{array}$ & 3.19 & 64 & 0.48770 \\
\hline $\begin{array}{l}\text { 4. Availability within the company the management structure helps ensure the } \\
\text { success of the application of the ID-ABC. }\end{array}$ & 2.98 & 60 & 0.46691 \\
\hline $\begin{array}{l}\text { 5. The TD-ABC is longer from the absorbed system by the various levels of } \\
\text { management within the company. }\end{array}$ & 3.32 & 66 & 0.56256 \\
\hline \multirow{2}{*}{$\begin{array}{l}\text { 6. The company management has comvinced and absolute belief to support the } \\
\text { TD-ABC. } \\
\text { The overall average }\end{array}$} & 3.9 & 78 & 0.54167 \\
\hline & 3.5 & 70 & 0.52529 \\
\hline
\end{tabular}

Table 3: Support of Top Management to apply TD-ABC

Source: As Created by the Author

According to the findings of table 4 it can be said that there has been positive weightage given to all the parameters but it was below average. This means that according to the views poised by the sample, there is a need of improving the accounting system in order to reap the benefit of the TD-ABC tool. The questions receiving more weightage is that the current accounting system can separate the direct and indirect cost associated with the system of production. The least weightage has been received in the question where the interviewer tried to see if the sample can recognize the different categories of resources required and the time taken by each component in the production process. Hence, little modification is required in the existing accounting system so that they can easily adopt the system of TD-ABC that is being proposed to them. 


\section{Macrothink}

International Journal of Accounting and Financial Reporting

ISSN 2162-3082 2017, Vol. 7, No. 1

\section{Table 4}

The results of descriptive statistics of the variable paragraphs availabilityadvanced accounting systen in Iraqi industrial companies that supports application of TDABC.

No. Paragraphs mean

1. Accounting systems in the company is able to separate the costs to both direct $3.1 \quad 62 \quad 0.88864$ and indirect.

2. Accounting system has the flexibility to make the application of system $\quad 2.45 \quad 50 \quad 0.56256$ TDABC much easier time.

3. Accounting systems in place capable to prepare the rates of load time for the $2.23 \quad 45 \quad 0.56256$ costs of activities from which to determine the rates of product cost accurately.

4. Accounting systems currently in place in the compary is able to determine the $2.01 \quad 12 \quad 0.48770$ actual energy for each group of resources.

5. Applicable accounting systems able to identify different groups of resources $\quad 2.12 \quad \begin{array}{lll}0 & 0.54167\end{array}$ (departments) that implement the cost.

6. Accounting systems currently in place in the company is able to debermine $\quad 2.06 \quad 41 \quad 0.46691$ the engines (the causes of) the time required to carry out any activity or event within the activity.

The overall average

Table 4: Availability of accounting system to support TD-ABC

Source: As Created by the Author

According to table 5, it can be stated that the positive weightage given to each factors were above the average level of $60 \%$. The implication of such a finding is that according to the opinion of the sample there is existence of scientific competencies within the domain of IIC that can help in successful implementation of the TD-ABC tool. The factor which state that the top management people takes enough care to influence and attract highly efficient workers receives the highest weightage. From this table it can be inferred that the workers of IIC do possess the knowledge about TD-ABC. They only require an in-depth knowledge along with the necessary skills to be successful in using the modern system. 


\section{Table 5}

The results of descriptive statistics for paragraphs of variable availabilitythe scientific and professional conpetencies in Iraqi industrial companies that support application of TDABC.

\begin{tabular}{|c|c|c|c|c|}
\hline No. & Paragraphs & mean & $\%$ & St.d \\
\hline 1. & $\begin{array}{l}\text { The company management concerned with attracting highly qualified } \\
\text { employees of the company. }\end{array}$ & 3.70 & 74 & 1.26920 \\
\hline 2. & $\begin{array}{l}\text { The employees of the company have available to have a high efficiency that } \\
\text { enables them to apply TDABC system. }\end{array}$ & 3.15 & 63 & 1.14770 \\
\hline 3. & $\begin{array}{l}\text { The employees of the company have avalable sufficient operational } \\
\text { experience that enables them to apply the system of IDABC. }\end{array}$ & 3.25 & 65 & 1.15631 \\
\hline 4. & $\begin{array}{l}\text { The employees of the company have the ability to prepare the rates of time } \\
\text { to load the costs of activities from which to determine the exact cost of the } \\
\text { product. }\end{array}$ & 3.21 & 64 & 1.15427 \\
\hline 5. & $\begin{array}{l}\text { The company has the ability to prepare human resources for the application } \\
\text { of the time driven activities system. }\end{array}$ & 3.3 & 66 & 1.22434 \\
\hline \multirow[t]{2}{*}{6.} & $\begin{array}{l}\text { Availability at the company experts can be hired to figure out how to apply } \\
\text { the system of the time driven activities. }\end{array}$ & 3.4 & 68 & 1.12588 \\
\hline & The overall average & 3.33 & 66 & 0.75967 \\
\hline
\end{tabular}

Table 5: Scientific and Professional Competencies in IIC

Source: As Created by the Author

The fundamental flaw of the existing system is that it cannot disintegrate the costing associated with the complex procedure of production. Along with modernization there has been diversification in the product line along with increase in the complexities involved in the production process. This created a need to change the outlook in which costing system works. Table 6 tries to highlight the same factors. All the factors receive positive weightage under this table. The factor receiving the greatest weight of $91 \%$ is that companies are involved in producing complex and a wide variety of products in their production line. The question of TD-ABC being more useful than the presently used method received the least weightage and this is obvious as the samples are not accustomed with that system. This findings highlights the fact that there is presence of awareness about the TD-ABC system within the IIC. At the same time people require thorough training in using this tool along with training about the beneficial effect of this tool. It is only then their misconception about their existing system being the best is going to get eradicated. 


\section{Ml Macrothink}

International Journal of Accounting and Financial Reporting

ISSN 2162-3082 2017, Vol. 7, No. 1

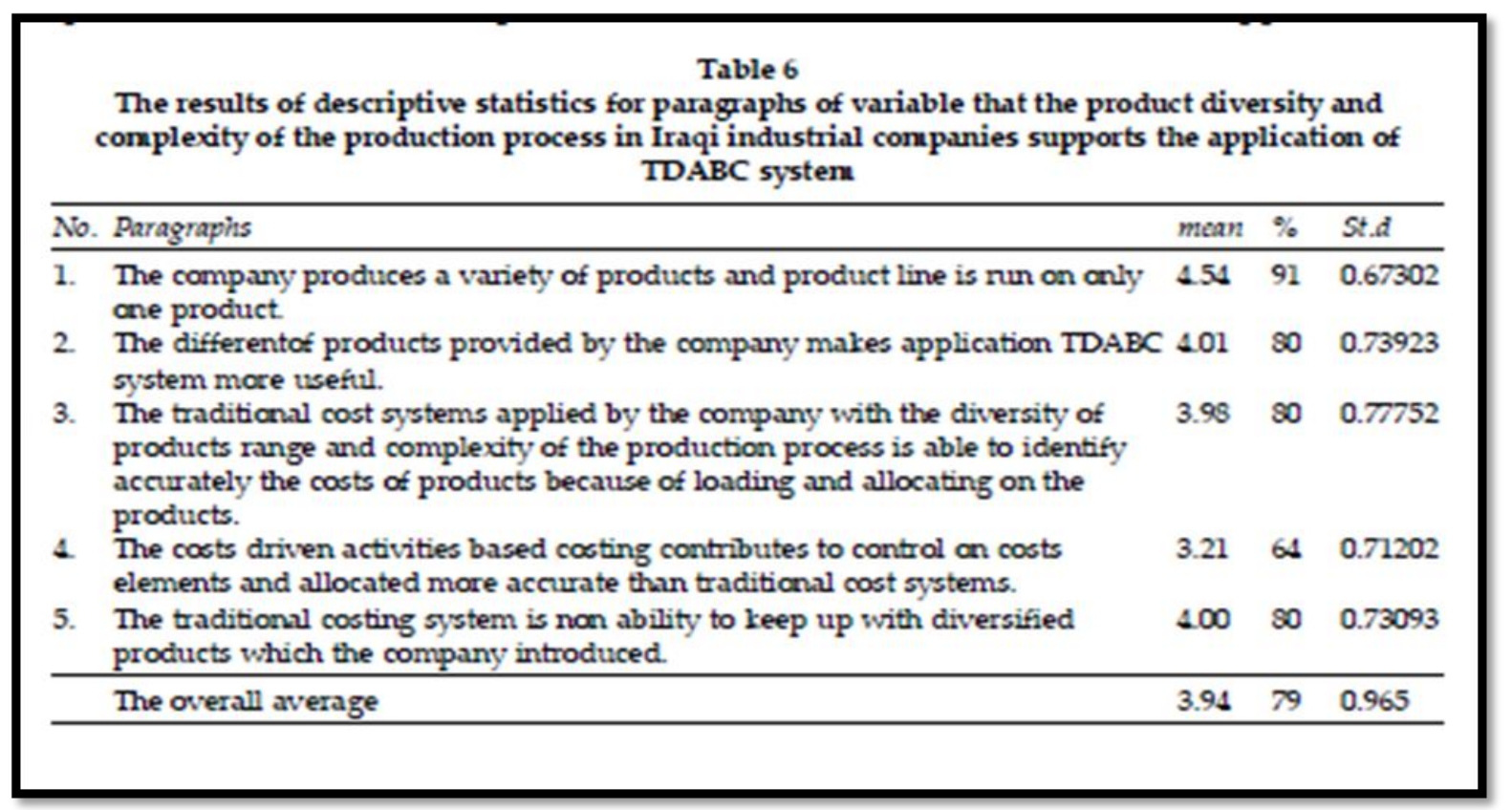

Table 6: Product Diversity and Complexity support the TD-ABC

Source: As Created by the Author

The questions in Table 7 try to find out the economic justification of implementing this new system. All the variables received positive weightage as calculated from the samples. Thus it can be said that there is reduction in the cost of production if the modern system is used. This is because the modern system proposes to use the concept of time in determining the cost of different steps of production. Also the key objective of any firm is to manage the use of energy and that is reduced under the modern system. According to the table 7 as given below, the factors receiving the highest priority is that $\mathrm{TD}-\mathrm{ABC}$ has the potentiality to reduce and remove the constraints involved in accounting for indirect cost that possess hindrance in the reduction of overall cost. On other hand, the least weight has been received in the parameter which state that this system can or has the capability to improve the company on the basis of competition in global and domestic markets. Hence, according to the researcher there is going to be improvement of the company in terms of their competitive positions but the people of Iraq does not have any idea about it since they are not accustomed with this system yet. 


\section{Table 7}

The results of descriptive statistics of the paragraphs of the variable of application of the TDABC in Iraqi industrial conpanies econonically justified

\begin{tabular}{|c|c|c|c|c|}
\hline \multicolumn{2}{|c|}{ No. Paragraphs } & \multirow{2}{*}{$\frac{\text { mean }}{3 . x 0}$} & \multirow{2}{*}{$\begin{array}{l}\% \\
74\end{array}$} & \multirow{2}{*}{$\frac{S t . d}{0.656}$} \\
\hline 1. & $\begin{array}{l}\text { The benefit derived from the application of IDABC system increased the cost } \\
\text { of practice it. }\end{array}$ & & & \\
\hline 2. & $\begin{array}{l}\text { The application of IDABC in the company contributes to the reduction of } \\
\text { production corts. }\end{array}$ & 3.99 & $\$$ & 0.567 \\
\hline 3. & $\begin{array}{l}\text { The IDABC System trying to remove all the activities that strain the } \\
\text { company's indirect costs and unnecessary expenses. }\end{array}$ & 4.10 & 82 & 0.567 \\
\hline 4. & $\begin{array}{l}\text { The application of TDABC system helps to take preventive measures for the } \\
\text { production to decrease the coots of production. }\end{array}$ & 3.98 & $\infty$ & 0.654 \\
\hline 5. & $\begin{array}{l}\text { The application of TDABC increases the efficiency of the productive phase's } \\
\text { system, leading to lower production costs. }\end{array}$ & 3.83 & 77 & 0.876 \\
\hline \multirow[t]{2}{*}{6.} & $\begin{array}{l}\text { The IDABC contributes to improve the competitive level of the commodity in } \\
\text { the domestic and global markets. }\end{array}$ & 3.4 & 68 & 0.564 \\
\hline & The overall average & 3.83 & 76 & 1.0276 \\
\hline
\end{tabular}

Table 7: TD-ABC implementation is Economically Justified

Source: As Created by the Author

\subsection{Hypothesis Testing}

The previously stated hypotheses are now being tested with the help of the tool called OneSample $T$ test. The results obtain through this test is going to validate the findings of the arithmetic mean as derived from the response given by the sample with regards to the questionnaire given to them.

\subsubsection{Testing of Hypothesis 1}

According to the first hypothesis:

"Tendency towards abutment of the top managements of the IIC to implement the TD-ABC"

In order to verify this hypothesis the results of the One-Sample $\mathrm{T}$ test has been given in the table below: 


\begin{tabular}{|c|c|c|c|c|c|c|}
\hline \multicolumn{7}{|c|}{ One-Sanple Statistics } \\
\hline & $N$ & Mean & Std. Deviation & Std. Error Mcan & & \\
\hline$\underline{x_{1}}$ & 62 & 3.3280 & .52529 & .06671 & & \\
\hline \multicolumn{7}{|c|}{ One-Saniple Test } \\
\hline \multicolumn{7}{|c|}{ Test Value $=3$} \\
\hline \multicolumn{7}{|c|}{$95 \%$ Confidence Interval of the Difference } \\
\hline & $t$ & $d f$ & Sig-(2-tailled) & Mean Difference & Lower & Upper \\
\hline$\underline{x 1}$ & 4916 & 63 & .00 & .32796 & 1946 & .4614 \\
\hline
\end{tabular}

Table 8: Result of Hypothesis 1

Source: As Calculated and Created by the Author

According to the above table it can be said that there is significance of the $\mathrm{T}$ value. This implies that the response of the sample with regards to the top management supporting TD$A B C$ is consistent with the statistical value obtained. This result is obtained because the topnotch managers of the company are aware of this modern system and the benefits it can yield to the company. Hence, the first hypothesis is accepted at $95 \%$ confidence interval.

\subsubsection{Testing of Hypothesis 2}

According to the Second hypothesis:

"There is availability of professional and scientific scope within the IIC to apply the modern system"

In order to verify this hypothesis the results of the One-Sample T test has been given in the table below:

\begin{tabular}{|c|c|c|c|c|c|c|}
\hline \multicolumn{7}{|c|}{ One-Sample Statistics } \\
\hline & $\mathrm{N}$ & Mean & Std. Deviation & Std. Error Mcan & & \\
\hline$\underline{x_{2}}$ & 64 & 2.3490 & .29505 & .03688 & & \\
\hline \multicolumn{7}{|c|}{ One-Sample Statistics } \\
\hline & $N$ & Mean & Std. Deviation & Std. Error Mean & & \\
\hline \multirow[t]{4}{*}{$\underline{X 2}$} & 64 & 2.3490 & .29505 & .03658 & & \\
\hline & & & & Test $V a i$ & lue $=3$ & \\
\hline & & & & & $95 \%$ Confidence In & 1 of the Difference \\
\hline & $T$ & $d f$ & Sig. (2-tailed) & Mean Difference & Lower & Upper \\
\hline$\underline{x}$ & 17.652 & 63 & .000 & -.65104 & -.7247 & -.5773 \\
\hline
\end{tabular}

Table 9: Result of Hypothesis 2

Source: As Calculated and Created by the Author

According to the above table it can be said that there is significance of the $\mathrm{T}$ value at 0.00 level. In this case it can be said that the sample interviewed believes that there is scope for improvement in the existing system in order to lay a proper base for the upcoming modern 
accounting system. Here, the second hypothesis is rejected at $95 \%$ confidence interval.

\subsubsection{Testing of Hypothesis 3}

According to the Third hypothesis:

"There is existence of the high level system of accounting that can support or provide backup to the newly system proposed to be implemented"

In order to verify this hypothesis the results of the One-Sample $\mathrm{T}$ test has been given in the table below:

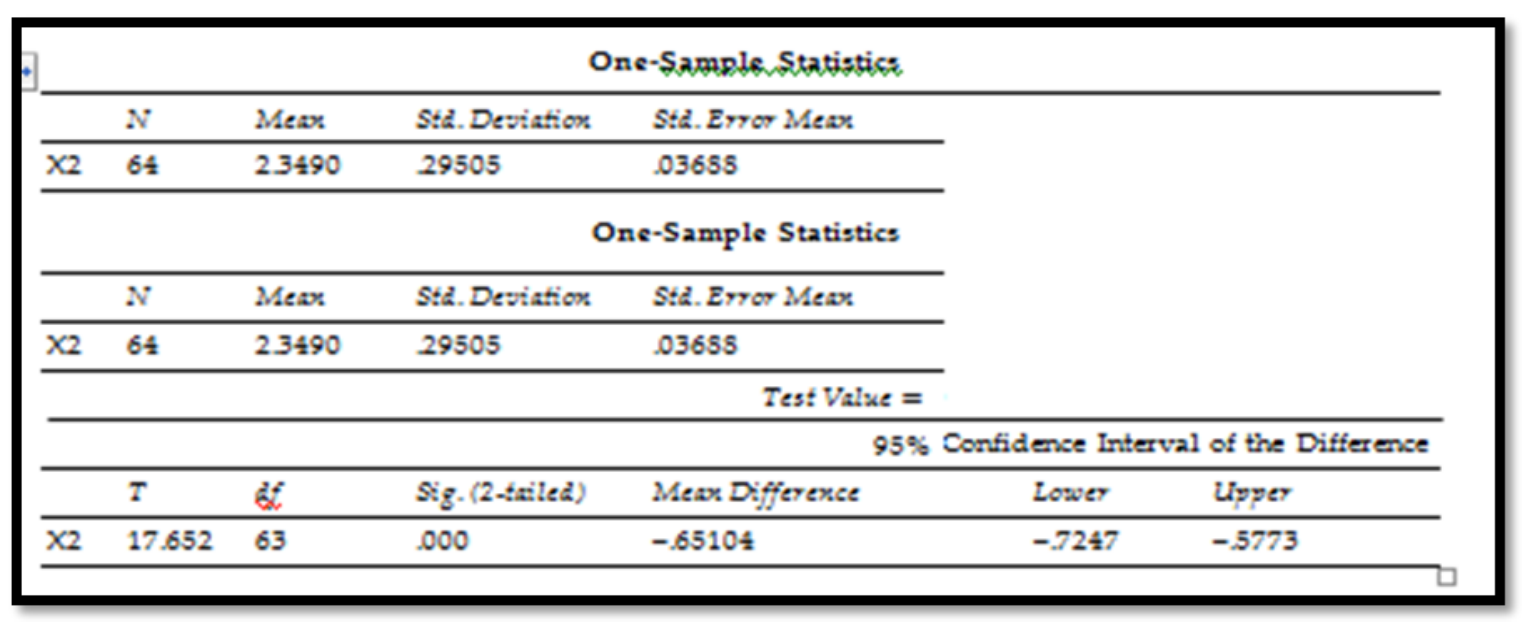

Table 10: Result of Hypothesis 3

Source: As Calculated and Created by the Author

According to the above table it can be said that there is significance of the largest observable value of $\mathrm{T}$ at 0.00 level. From the response of the sample and statistical result the third hypothesis is accepted at the $95 \%$ confidence level.

\subsubsection{Testing of Hypothesis 4}

According to the Fourth hypothesis:

"The production processes of IIC are complex and the diversity in their products that require that generates the need to apply TD-ABC"

In order to verify this hypothesis the results of the One-Sample $\mathrm{T}$ test has been given in the table below: 


\begin{tabular}{|c|c|c|c|c|c|c|}
\hline \multicolumn{7}{|c|}{ One-Sanple Statistics } \\
\hline & $N$ & Mann & Std. Deviation & Std. Error Mean & & \\
\hline \multirow[t]{5}{*}{$x_{4}$} & 64 & 3.3516 & .99430 & .12429 & & \\
\hline & & & & One-Sanple T & & \\
\hline & & & & Test Vailt & & \\
\hline & & & & & $95 \%$ Confidence In & I of the Difference \\
\hline & $T$ & $D f$ & Sig. (2-tailed) & Mean Difference & Lower & Upper \\
\hline$x_{4}$ & 2829 & 63 & .006 & .35156 & .1032 & .5999 \\
\hline
\end{tabular}

Table 11: Result of Hypothesis 4

Source: As Calculated and Created by the Author

The $\mathrm{T}$ value in this hypothesis is greater than the table of $\mathrm{T}$ value which shows significance at 0.00 level. In this case there is existence of harmony between the answer given by the respondents and the statistical figures. This hypothesis is accepted at $95 \%$ level of confidence.

\subsubsection{Testing of Hypothesis 5}

According to the Fifth hypothesis:

"TD-ABC's application and implementation within the industrial domain of Iraq is economically justified"

In order to verify this hypothesis the results of the One-Sample T test has been given in the table below:

\begin{tabular}{|c|c|c|c|c|c|c|}
\hline \multicolumn{7}{|c|}{ One-Sanple Statistics } \\
\hline & $N$ & Mann & Std. Deviation & Std. Error Mean & & \\
\hline \multirow[t]{5}{*}{ X5 } & 64 & 3.8542 & 1.02762 & .12845 & & \\
\hline & & & & One-Sanple Te & & \\
\hline & & & & Test $V$ & & \\
\hline & & & & & $95 \%$ Confidence & val of the Differeno \\
\hline & $t$ & $d f$ & Sig. (2-tailed) & Moun Difference & Lower & Unper \\
\hline$\times 5$ & 6.650 & 63 & .000 & .85417 & .5975 & 1.1109 \\
\hline
\end{tabular}

Table 12: Result of Hypothesis 5 
Source: As Calculated and Created by the Author

The $\mathrm{T}$ value in this hypothesis is greater than the table of $\mathrm{T}$ value which shows significance at 0.00 level. In this case the respondent sees that there is economic significance involved in application of the TD-ABC. This hypothesis is accepted at $95 \%$ level of confidence.

The findings of the hypothesis are summarized in the table below:

\begin{tabular}{|c|c|c|}
\hline \multicolumn{3}{|c|}{ The Summary of the Testing hypotheses Summary } \\
\hline The hypothesis & The decision & The result \\
\hline First & Accept the hypothesis & $\begin{array}{l}\text { The top management trends in Iraqi industrial companies } \\
\text { support the application of TDABC system. }\end{array}$ \\
\hline Second & reject the hypothesis & $\begin{array}{l}\text { Availability advanced accounting systems in Iraqi industrial } \\
\text { companies support application of TDABC system. }\end{array}$ \\
\hline Third & Accept the hypothesis & $\begin{array}{l}\text { The product diversity and complexity of the production } \\
\text { process in Iraqi industrial companies supports application of } \\
\text { IDABC system. }\end{array}$ \\
\hline Fourth & Accept the hypothesis & $\begin{array}{l}\text { Availabilitythe scientific and professional competencies in } \\
\text { Iraqi industrial companies that support application of TDABC } \\
\text { system. }\end{array}$ \\
\hline Fifth & Accept the hypothesis & $\begin{array}{l}\text { The application of TDABC in the Iraqi industrial companies } \\
\text { economically justified. }\end{array}$ \\
\hline
\end{tabular}

Table 13: Summary of the findings

Source: Created by the Author

\section{Conclusion}

The outcomes of the hypothesis testing and the observations about the entire research topic can be summed up under few points as follows:

- The pre-conditions necessary for application of the new costing system named TD$\mathrm{ABC}$ has been found in almost all the samples taken from IIC. Consistency can be found in between the sample used for studying and existence of the real components necessary for introducing TD-ABC.

- Data on arithmetic average of the sample collected to analyze the depth of the support as provided by the top-management in implementing TD-ABC suggests that the administration tries to provide a background to this system of implementation.

- The sample variable showing the already existing high level accounting system that could have provide a firm background for implementation TD-ABC within the IIC is very low. The average is around 2.43 which implies that the companies needs lots of amendments of their existing system in order to provide a strong background for implementation of the new system and remain in pace with the advancement of scientific development.

- There is existence of complexity and diversity in the production process within the industrial companies of Iraq. This complexity and diversity supports the need to apply $\mathrm{TD}-\mathrm{ABC}$ within those industries. 


\section{Macrothink}

International Journal of Accounting and Financial Reporting

- Statistics suggest average arithmetic mean of around 3.3516 in the variables that indicates the existence of well trained highly qualified staffin the industries. The existence of qualified staff within the industrial company indicates the existence of infrastructure and scope of the industry to adept to the new system of TD-ABC.

- Observation suggests that there is existence of several factors that causes hindrances of calculating the indirect cost of the company in its method of operation. Hence by applying the tools of TD-ABC this restrictions can be reduced and the company can calculate the cost effectively. This tool can prove to be economically beneficial for the company.

\section{Recommendations}

After accessing the entire report, the places where the industrial companies of Iraq can change their strategies and outlook for betterment and success of the modern system of accounting has been given as follows:

- The companies should expand their views, prioritize and follow the happenings of other successful international companies. By accessing the ways in which those companies has been successful in implementing and reaping the benefit of the new system, the top managements of IIC can help their respective company's in doing the same.

- Raising awareness is a very important factor for the success of any strategy. The employees need to be made aware of the system, its benefits and the difference between the existing traditional system and the modern version. After raising the awareness they should be provided with special training courses so that they can successfully use the tool in their course of operation.

- The TD-ABC can be successfully implemented by increasing the efficiency of the employees in using this tool. It is preferable to construct a separate cell within the administrative system that should be responsible for looking after this system and empowering human resource through proper training.

- The system should be used in companies using a diverse range of product mix in their production system. Through this tool the efficiency of each component of product mix can be analyzed. This is going to help the company in identifying the most efficient product mix and the one which has negligible impact on the production process. After identification, by discarding the mix which contributes the least to the production process, a bulk amount of cost associated with that mix can be saved.

- An extensive and exhaustive research on the companies' using the system of TD-ABC needs to be carried on to get a thorough understanding of the tool. Company belonging to industrial, financial, commercial and service sector should be chosen randomly to understand the industry where the tool causes maximum benefits. 


\section{Macrothink}

International Journal of Accounting and Financial Reporting

ISSN 2162-3082

2017, Vol. 7, No. 1

\section{References}

Abu Rahma, Mohammed Abdullah(2008), "the availability of the elements of the application system budgets on the basis of activities in the municipalities of the Gaza Strip/Empirical Study", Azza University, Master's degree in accounting and finance.

Dhergham, Maher(2005),"Evaluating the possibility of applying document activities in the Palestinian government hospitals in the Gaza Strip costs System: An Empirical Study", unpublished PhD thesis, the Arab Academy for Banking and Financial Sciences, Amman, Jordan.

Dhergham,Maher(2007),"The availability of the basic components necessary to implement the system the costs of activities in the industrial companies in the Gaza Strip: An Empirical Study," Journal of the Islamic University of Gaza, Vol. 15,No.2,pp.267-269.

Everaert,P. and W. Bruggeman.(2007),"Time-driven activity-based costing: Exploring the underlying model” Cost Management(March/April)pp: 16-20.

Everaert,P.,W.Bruggeman,G.Sarens,S.R.AndersonandY.Levant.(2008)“Costmodelingin logistics using time-driven ABC: Experiences from a wholesaler” International Journal of Physical Distribution and Logistics Management 38(3),pp.172-191.

Garrison R. and Noreen, E. (2003), "Managerial Accounting", 10Th ed., New York: McGraw-Hill.

Garrison R. and Noreen, E. (2008), "Managerial Accounting”, 12Th ed., New York: McGraw-Hill.

GharwrI,MagdiAli(2008), “Onthebasisofcost-orientedtime/activityanewapproachto increase the product" Egyptian Journal of Commercial Studies, Faculty of Commerce, Mansoura University, No.2, vol.32.pp.5-25.

Hon, J. and S. Chu,(2012), “Implementation of Time-Driven Activity-Based Costing: A Case Study of Aerospace Precision Casting Factory", Proceedings of the Asia Pacific Industrial Engineering and Management Systems Conference, pp426-435.

Johnson, P.F., 2014. Purchasing and supply management. McGraw-Hill Higher Education. Journal of Performance Management,vol.20,No. 3,pp:16-28.

Kaplan R. and S.Anderson,(2004), “Time-Driven Activity Based Costing”, Harvard Business Review, vol. 82,No.11.pp.131-138.

Kaplan R. and S. Anderson,(2007), “Time-Driven Activity Based Costing: a Simpler and more Powerful to higher profits”, Harvard Business school, Press, Boston.

KaplanR. and S. Anderson,(2007), "The Innovation of Time-Driven Activity Based Costing" Cost Management, Vol.21,No.2, Mar/Apr, pp5-15.

Kaplan R. and S. Anderson,(2007),“The Speed Reading Organization”, Business Finance, Vol.13, No.6,pp 39-4 


\section{Macrothink}

International Journal of Accounting and Financial Reporting ISSN 2162-3082 2017, Vol. 7, No. 1

Kaplan, Robert S., and Robin Cooper, "Activity-Based System: Measuring the Cost of Resource Usage Accounting“, Accounting Horizons(September1992):p.1-13.

LambinoC.(2007), “Timedrivenactivitybasedcosting”,GovernmentFinanceReview,vol.23, o.4, pp:74-75.

Ljilja, A. and G. Mila,(2010),'Time-Driven Activity Based Costing", Economic Themes, XLVIII,no.4,pp 498-511.

Max M.(2007), “Leveraging process documentation for time-driven activity based costing”.

Oleg D. and R. Czech, (2011),"Method Time Driven Activity Based Costing-Literature Review”, Journal of Applied Economic Sciences”, Vol. VIL Issue1(15),pp.7-15.

Salim, Ahmed Hisham (2010), "Proposed Model for the cost on the basis of activity using the time engine(TDABC) application on the logistic business in commercial companies" EgyptianJournalofCommercialStudies,FacultyofCommerce,MansouraUniversity, the second issue, Volume IV Thirty.

Schuhmacher, K. and Burkert, M., 2014, August. Traditional ABC and Time-Driven ABC: An Experimental Investigation. AAA.

Siguenay-Guzman, Lorena and Abbeele Alexandra Van den and Cattrysse, Dirk (2014), "Time-Driven Activity-Based Costing Systemsfor Cataloguing Processes: A Case Study "Liber QuarterlyVol.23Issue2, pp:160-186.

Siguenza-Guzman,L., VandenAbbeele,A., Vandewalle,J., Verhaaren,H., andCattrysse, D.(2013), "Recent evolutions in costing systems: A literature review of Time-Driven Activity-Based Costing”. Rebel-Review of Business and EconomicLiterature, 58(1),pp:34-64.

Thomson,J., and GurawkaJ.,(2005), “Sorting out the clutter” Strategic finance, Vol.87,No.2, August,p.27-33.

\section{Copyright Disclaimer}

Copyright for this article is retained by the author(s), with first publication rights granted to the journal.

This is an open-access article distributed under the terms and conditions of the Creative Commons Attribution license (http://creativecommons.org/licenses/by/3.0/). 